University of Michigan Law School

University of Michigan Law School Scholarship Repository

\title{
Racial Profiling under Attack
}

\author{
Samuel R. Gross \\ University of Michigan Law School, srgross@umich.edu \\ D. Livingston \\ Columbia Law School
}

Available at: https://repository.law.umich.edu/articles/1589

Follow this and additional works at: https://repository.law.umich.edu/articles

Part of the Civil Rights and Discrimination Commons, Criminal Law Commons, Law and Race Commons, and the Law Enforcement and Corrections Commons

\section{Recommended Citation}

Gross, Samuel R. "Racial Profiling under Attack." D. Livingston, co-author. Colum. L. Rev. 102, no. 5 (2002): 1413-38.

This Article is brought to you for free and open access by the Faculty Scholarship at University of Michigan Law School Scholarship Repository. It has been accepted for inclusion in Articles by an authorized administrator of University of Michigan Law School Scholarship Repository. For more information, please contact mlaw.repository@umich.edu. 


\title{
ESSAY
}

\section{RACIAL PROFILING UNDER ATTACK}

\author{
Samuel R. Gross* \\ Debra Livingston **
}

The events of September 11, 2001, have sparked a fierce debate over racial profiling. Many who readily condemned the practice a year ago have had second thoughts. In the wake of September 11, the Department of Justice initiated a program of interviewing thousands of men who arrived in this country in the past two years from countries with an al Qaeda presence-a program that some attack as racial profiling, and others defend as proper law enforcement. In this Essay, Professors Cross and Livingston use that program as the focus of a discussion of the meaning of racial profiling, its use in a variety of contexts, and its relationship to other police practices that take race or ethnicity into account.

\section{INTRODUCTION}

We had just reached a consensus on racial profiling. By September 10,2001 , virtually everyone, from Jesse Jackson to Al Gore to George W. Bush to John Ashcroft, agreed that racial profiling was very bad. We also knew what racial profiling was: Police officers would stop, question, and search African American and Hispanic citizens disproportionately, because of their race or ethnicity, in order to try to catch common criminals. All this has changed in the wake of the September 11 attacks on the World Trade Center and the Pentagon. Now racial profiling is more likely to mean security checks or federal investigations that target Muslim men from Middle Eastern countries, in order to try to catch terrorists. And now lots of people are for it. In the fall of $1999,81 \%$ of respondents in a national poll said they disapproved of "racial profiling," which was defined as the practice by some police officers of stopping "motorists of certain racial or ethnic groups because the officers believe that these groups are more likely than others to commit certain types of crimes." 1 Two years later, $58 \%$ said they favored "requiring Arabs, including those who are U.S. citizens, to undergo special, more intensive secur-

* Thomas \& Mabel Long Professor of Law, University of Michigan Law School.

** Professor of Law, Columbia Law School. The authors thank Karima Benoune, Harold Edgar, Phoebe Ellsworth, James Forman, Saul Green, Gerard Lynch, William Stuntz, and Richard Uviller for helpful comments on earlier drafts, and Scott Laton, AnnaRose Mathieson, and Katherine Taylor for research assistance. This work was supported in part by funds from the Cook endowment of the University of Michigan Law School.

1. Gallup Poll, Sept. 24, 1999-Nov. 16, 1999, Public Opinion Online, The Roper Center at the University of Connecticut, available at LEXIS, News Library, Rpoll file [hereinafter Roper Data Basel (describing results from question 1, accession \#0346115, and question 9 , accession \#0346123). 
ity checks before boarding airplanes in the U.S." 2 This new attitude has emerged across the political spectrum. ${ }^{3}$ Even as stalwart a civil libertarian as Floyd Abrams, the celebrated First Amendment lawyer, has said that under the circumstances we now face, "it seems entirely appropriate to look harder at such people. Remember, Justice [Robert] Jackson said 'the Constitution is not a suicide pact." "4

Needless to say, racial profiling has not become a national fad. Most newfound supporters are reluctant and ambivalent, and most public officials continue to say they oppose the practice. There is certainly no new national consensus in favor of racial profiling. Quite the opposite: The antiterrorist investigations that followed September 11 have generated a fresh set of controversies over the issue. But the nature of the debate has changed. Before September 11, the disputes appeared to be factual. Critics would argue that the police acted on the basis of race, and the police would deny it. Now the differences are more likely to be definitional or frankly normative: Does it constitute racial profiling to do what the Department of Justice says it is doing? And if so, are the Department's actions nevertheless justified?

To our minds, neither the pre- nor the post-September 11 debates have been very illuminating. The problem may be that before September 11 there was too much agreement on the issue, at least on the surface. Racial profiling continued to occur, as it does today, but since no public official would defend it, the game turned entirely on labeling. If a practice was successfully tagged as racial profiling, the cops lost; if not, they won. Since September 11, the debate has shifted but not deepened-at least not appreciably. The division now is between those who say that we can no longer afford to reject racial profiling out of hand, and those who insist that this is a principle that must not be compromised. In both settings, before September 11 and after, no one has stopped to analyze what racial profiling is, and what makes it stand out as a special law enforcement problem. This Essay addresses these questions.

2. Id. (describing results from question 1 , accession $\# 0387144$, from the Sept. 14, 2001 Gallup Poll); see also David E. Rovella, Pro-Police Opinions on the Rise, Poll Says Wiretaps, Profiling Gain Juror Support, Nat'l L.J., Jan. 21, 2002, at Al (finding that 59\% of adults eligible for jury duty say that profiling is acceptable in certain circumstances).

3. See, e.g., Stanley Crouch, Drawing the Line on Racial Profiling, N.Y. Daily News, Oct. 4, 2001, at 41 (arguing that current Arab American profiling differs from African American profiling); Editorial, Profiling Debate Resumes, Denver Post, Oct. 3, 2001, at B6 (suggesting that race should be taken into account in finding law enforcement targets); Michael Kinsley, When Is Racial Profiling Okay?, Wash. Post, Sept. 30, 2001, at B7 (arguing that racial profiling is sometimes appropriate, and may be acceptable at airport security checkpoints); Dorothy Rabinowitz, Hijacking History, Wall St. J., Dec. 7, 2001, at A18 (arguing that Arab American profiling is markedly different from past forms of racial profiling); Stephen J. Singer, Racial Profiling Also Has a Good Side, Newsday, Sept. 25, 2001, at A38 (suggesting that race, in conjunction with other factors, can signal the need for further investigation).

4. Henry Weinstein et al, Racial Profiling Gains Support as Search Tactic, L.A. Times, Sept. 24, 2001, at Al (discussing airport security). 
We do not expect to change people's minds or to resolve differences of opinion about the appropriateness of programs that have been called racial profiling. We do not entirely agree with each other. Nor do we present a general normative theory of racial profiling or a detailed legal analysis. Our goal is more limited: to shed some light on the underlying issues by examining racial profiling in the context of other police practices that take race or ethnicity into account. Some of these practices are among the worst expressions of racism in modern America, while others are perfectly justified. To locate a police practice along this range we need to know in concrete detail not just who the authorities target, and why, but what they do to these people and why they do it. The label "racial profiling," however carefully applied, is not very informative.

\section{I.}

As we use the term, "racial profiling" occurs whenever a law enforcement officer questions, stops, arrests, searches, or otherwise investigates a person because the officer believes that members of that person's racial or ethnic group are more likely than the population at large to commit the sort of crime the officer is investigating. The essence of racial profiling is a global judgment that the targeted group-before September 11, usually African Americans or Hispanics-is more prone to commit crime in general, or to commit a particular type of crime, than other racial or ethnic groups. If the officer's conduct is based at least in part on such a general racial or ethnic judgment, it does not matter if she uses other criteria as well in deciding on her course of action. It is racial profiling to target young black men on the basis of a belief that they are more likely than others to commit crimes, even though black women and older black men are not directly affected. ${ }^{5}$

It is not racial profiling for an officer to question, stop, search, arrest, or otherwise investigate a person because his race or ethnicity matches information about a perpetrator of a specific crime that the officer is investigating. That use of race-which usually occurs when there is a racially specific description of the criminal-does not entail a global judgment about a racial or ethnic group as a whole. Likewise, a deliberate practice of discrimination between known suspects of different racesstopping all speeders but giving tickets to black drivers only, and warnings to whites-is a violation of the Equal Protection Clause of the Fourteenth Amendment, but it is not racial profiling. Racial profiling can occur in almost any type of criminal investigation. It has received particular attention in the context of highway drug interdiction, and more recently, of course, in investigations of terrorism.

5. For a similar definition, see Deborah Ramirez et al., A Resource Guide on Racial Profiling Data Collection Systems (Nov. 2000) (defining racial profiling as relying on race rather than behavior in police initiated actions), at http://www.usdoj.gov/cops/pdf/cp_ resources/pubs_prod/police_practices_handout/Section6.pdf (on file with the Columbia Law Review). 
Others have offered somewhat different definitions of racial profiling. ${ }^{6}$ We are satisfied with our own definition, even though, as we will see, some cases cannot be neatly classified. We will not defend it at any length, however, because one of our main points is that it is a mistake to focus excessively on labels.

We will discuss the constitutionality of racial profiling equally briefly. A pair of comparatively old Supreme Court cases suggests that under the Fourth Amendment it is constitutional to use race as one factor among several for a decision to stop a person, but not as the sole basis. ${ }^{7}$ Some courts continue to follow that rule; ${ }^{8}$ others have held that race may not be included in a profile that is used as a basis for individualized suspicion under the Fourth Amendment. ${ }^{9}$ Racial profiling may also be challenged under the Equal Protection Clause of the Fourteenth Amendment. ${ }^{10}$ The Equal Protection Clause applies to all government action, including early stages of police investigations-surveillance in public places, ostensibly noncoercive questioning, requests for consent to conduct searchesthat are not governed by the Fourth Amendment because they do not

6. Some states, agencies, and law enforcement organizations define racial profiling narrowly as police initiated conduct that is based exclusively or solely on race. See, e.g., Md. Code Ann., Transp. II $\$ 25-113$ (Michie Supp. 2001) (prohibiting use of race as sole justification for traffic stop); R.I. Gen. Laws $\S 31-21.1-2$ (2000) (defining racial profiling as police action based solely on a person's race); Portland Police Bureau, Community Policing News, (Dec. 2000-Jan. 2001) (defining racial profiling as " $t$ t] he use of race as the sole basis for justifying traffic stops or other police action"), at http://www.portlandpolice bureau.com/news1200.html (on file with the Columbia Law Review). Other agencies and law enforcement associations have defined racial profiling more broadly as police action that is based on a suspect's race, even in combination with other factors. See, e.g., Office of the Att'y Gen., Ariz., Report on Racial Profiling (Jan. 2001) (asking law enforcement agencies to prohibit any reliance on race and/or ethnicity in stopping suspects), at http:// www.ag.state.az.us/law_enforcement/racial\%20profiling.pdf (on file with the Columbia Law Review); Tucson Police Dep't, General Orders, Constitutional Issues (May 2001) (prohibiting any consideration of race or ethnicity "except where race or ethnicity is part of an identifying description or characteristic of a possible suspect"), at http://www.ci. tucson.az.us./police/Public_lnfo/general_orders/general_orders.html (on file with the Columbia Law Review); Int'l Ass'n of Chiefs of Police, Sample Professional Traffic Stops Policy and Procedure, at http://www.theiacp.org/documents/index.cfm?fuseaction=docu ment\&document\#id=139 (last visited Feb. 7, 2002) (prohibiting use of race as a profile factor in determining probable cause) (on file with the Columbia Law Review). We have rejected the narrow definition because other factors are inevitably considered by the police. See infra text accompanying note 58.

7. United States v. Martinez-Fuerte, 428 U.S. 543, 565-66 (1976); United States v. Brignoni-Ponce, 422 U.S. 873, 887-88 (1975).

8. See United States v. Weaver, 966 F.2d 391, 394 n.2 (8th Cir. 1992); Castaneda v. Commonwealth, 376 S.E.2d 82, 83, 86 (Va. Ct. App. 1989).

9. See United States v. Montero-Camargo, 208 F.3d 1122, 1135 (9th Cir. 2000); Whitfield v. Bd. of Comm'rs, 837 F. Supp. 338, 340, 344 (D. Colo. 1993); People v. Bower, 597 P.2d 115, 119 (Cal. 1979); State v. Kuhn, 517 A.2d 162, 165 (N.J. Super. Ct. App. Div. 1986).

10. See State v. Soto, 734 A.2d 350 (N.J. Super. Ct. Law Div. 1996). 
involve "searches" or "seizures." 11 Under general equal protection principles, it may be that racial profiling, as we define it, is generally prohibited, at least in the absence of a finding that it is "narrowly tailored" to serve a "compelling state interest." 12 On the other hand, the common Fourth Amendment remedy-suppression-may not be available for equal protection violations; ${ }^{13}$ and in general, equal protection law in this area is not well developed. Any uncertainties about the legal status of racial profiling, however, do not concern us here because our focus is on the social, political, and moral issues that surround the practice.

II.

We will focus our discussion of racial and ethnic profiling on a concrete example. In November 2001, the Department of Justice began efforts to interview "more than 5,000. people nationwide-the majority Middle Eastern men ages eighteen to thirty-three who came here within the last two years on nonimmigrant visas-in search of information on terrorist organizations such as al Qaeda." 14 Four months later, the Justice Department announced that it would seek to interview 3,000 additional men, ages eighteen to forty-six, who entered the United States on nonimmigrant visas, between October 2001 and February 2002, from countries with an al Qaeda presence. ${ }^{15}$ The Department said that these men are not suspected of crimes but "might, either wittingly or unwittingly, be in the same circles, communities, or social groups as those engaged in terrorist activities." 16

Is the Justice Department's interview campaign an ethnic profiling program? Some civil libertarians, Arab American organizations, and lo-

11. E.g., United States v. Avery, 137 F.3d 343, 353 (6th Cir. 1998) (applying equal protection analysis to pre-contact stages of criminal investigation); United States $\mathrm{v}$. Travis, 62 F.3d 170, 172-76 (6th Cir. 1995) (same).

12. See, e.g., City of Richmond v. J. A. Croson Co., 488 U.S. 469, 486 (1989) (invalidating city's plan to set aside $30 \%$ of its construction budget for "Minority Business Enterprises" because the set-aside "was not narrowly tailored to accomplish a remedial purpose").

13. United States v. Armstrong, 517 U.S. 456, 461 n.2 (1996); see also Travis, 62 F.3d at 174 (finding it unnecessary to decide whether equal protection violation in police investigation requires suppression of evidence). See generally Pamela S. Karlan, Race, Rights and Remedies in Criminal Adjudication, 96 Mich. L. Rev. 2001, 2004 (1998) (exploring "the complications that arise in the definition of rights and in the operation of remedies when the Equal Protection Clause is used in criminal adjudication").

14. Allan Lengel, Arab Men in Detroit to be Asked to See U.S. Attorney, Wash. Post, Nov. 27, 2001, at A5. See Memorandum from the Deputy Attorney General, to All United States Attorneys and All Members of the Anti-Terrorism Task Forces (Nov. 9, 2001) (describing the manner of conducting interviews and topics to be covered), available at http://www.freepress.com/gallery/2001/interviews/index.htm (on file with the Columbia Law Review).

15. See New Round of Interviews Planned with Foreigners, Wall St. J., Mar. 21, 2002, at A8; Jonatban Peterson, U.S. Will lnterview More Foreigners in Fight on Terrorism, L.A. Times, Mar. 21, 2002, at A20 (citing number of interviews planned).

16. Peterson, supra note 15 (quoting Attorney General Ashcroft). 
cal police departments say it is; ${ }^{17}$ the Department of Justice says it is not. ${ }^{18}$ Who is right? And would answering this question tell us whether the Justice Department's program is appropriate? We will discuss these questions in the context of five factors. Some are staples of racial profiling debates; in fact, the first factor we address is generally treated as the sole defining issue. Others, however, are usually ignored, or are treated as involving background information rather than critical facts. In actual cases-as we will see in the discussion of several concrete examplesthese factors are often inextricably intertwined.

\section{A. Is the Investigation Based on Race or Ethnicity?}

In 1994, the New York City Police Department ("NYPD") launched an aggressive anti-gun campaign that resulted in the stopping and frisking of tens of thousands of young black and Hispanic men. ${ }^{19}$ Critics charged the Police Department with racial profiling. ${ }^{20}$ The Department replied that it deployed its officers in high-crime neighborhoods that are mostly minority dominated, and that the racial breakdown of those stopped corresponded to the racial makeup of victim descriptions of the perpetrators of violent crime, those arrested for violent crimes in New York City, and those described in 911 calls as carrying guns. ${ }^{21}$ ln a con-

17. See Fox Butterfield, Police are Split on Questioning of Mideast Men, N.Y. Times, Nov. 22, 2001, at A1 (discussing mixed reactions of local police departments to the Justice Department's interview program); Lisa Biank Fasig, ACLU Urges Police: Refuse to Help U.S. Government Detain Immigrants, Providence J.-Bull., Dec. 3, 2001, at B3 (noting charge of ACLU official that interview program is "nothing but thinly disguised racial profiling"); Chisun Lee, Let Us Not Be Suckers For Anybody, Village Voice, Jan. 1, 2002, at 52 (asserting that " $[t]$ he question today isn't whether law enforcement is engaging in racial profiling, it's how much"); Jim Schaefer, FBI to Question 840 Middle Eastern Men in Detroit Area, Detroit Free Press, Nov. 16, 2001 (reporting anger of Arab leaders and civil rights activists).

18. Michael Chertoff, Testimony Before the Senate Judiciary Committee Hearing on Preserving Freedoms While Defending Against Terrorism, Federal News Service, Nov. 28, 2001, available at LEXIS, News Library, News Group File, All.

19. The NYPD's strategic plan was articulated in a public document issued by the Department. New York Police Dep't, Police Strategy No. 1, Getting Guns Off the Streets of New York (1994). In 1999, New York's Attorney General issued a report in response to public concern about the impact of the use of aggressive stop-and-frisk tactics upon minority communities in New York City. This report analyzed some 175,000 "UF-250s"forms that NYPD officers were required to complete after many "stop" encounters-for the period of January 1, 1998 through March 31, 1999. This report concluded that about $51 \%$ of all persons "stopped" during the period were black and $33 \%$ were Hispanic. Office of Att'y Gen., New York, The New York City Police Department's "Stop \& Frisk" Practices 94 (Dec. 1, 1999) [hereinafter OAG Report], available at http://www.oag.state.ny.us/press/ reports/stop_frisk/stop_frisk.html (on file with the Columbia Law Review).

20. See U.S. Comm'n on Civil Rights, Police Practices and Civil Rights in New York City ch. 5, 16 (Aug. 2000) (noting that NYPD's stop and frisk data "strongly suggest that racial profiling plays some role in the stop and frisk practices of the overall Department").

21. See Safir Testimony before the U.S. Commission on Civil Rights, New York Hearing Transcript 165 (May 26, 1999); see also NYPD Response to the Draft Report of the U.S. Comm'n on Civil Rights-Police Practices and Civil Rights in New York City, 
text like that, it can be difficult to disentangle the competing factual claims and decide whether the NYPD deliberately relied on race in carrying out its anti-gun campaign. For the investigation we are focusing on, however, the Department of Justice has made the task somewhat easier by publicly acknowledging that it is seeking to interview primarily Middle Eastern men who have recently arrived from countries with an active al Qaeda presence. ${ }^{22}$

Is this ethnic profiling? In testimony before the Senate Judiciary Committee, Assistant Attorney General Michael Chertoff, who heads the Justice Department's Criminal Division, said no: "We have emphatically rejected ethnic profiling. What we have looked to are characteristics like country of issuance of passport ...."23 There is an important difference between ethnicity and nationality-and one with significant legal consequences. ${ }^{24}$ But in this context, the distinction may seem thin. As Justice Brennan pointed out in his concurrence in Saint Francis College v. AlKhazraji: "The line between discrimination based on 'ancestry or ethnic characteristics' and discrimination based on 'place or nation of . . . origin,' is not a bright one." 25 The Department's focus on visitors from countries with an active al Qaeda presence has admittedly produced an

Executive Summary 13 (2000); Press Release, Police Commissioner Safir Comments on State Attorney General's Stop and Frisk Report (Nov. 30, 1999) (on file with the Columbia Law Review).

22. See, e.g., Schaefer, supra note at 17 (citing statement by FBI agent in charge of interview program in Detroit that interviews "could be seen as profiling" because "all the men are Middle Eastern"). Justice Department investigators have stated that the interview program focuses on individuals arriving on nonimmigrant visas from nations where the al Qaeda network is active. See Peterson, supra note 15. Subjects of the interview program include visitors to the United States from Indonesia, the Philippines, and Malaysia, countries that do not fit any definition of the term "Middle Eastern" (itself a vague geographical designation). Telephone Interview with John Bell, Special Agent in Charge of DOJ Interview Program for the E.D. Mich. FBI (Feb. 1, 2002) [hereinafter Telephone Interview with John Bell]. The acknowledged fact that the interview list is composed primarily of Muslim men from the Middle East, however, has resulted in charges of not only ethnic profiling, but also religious profiling-a separate issue that we do not address.

23. Chertoff, supra note 18 .

24. These consequences include differences in the application of the equal protection clause. Gerald Neuman has explained:

Distinctions in federal law among aliens on the basis of their country of current nationality are not constitutionally suspect. Bilateral and multilateral treaties frequently create reciprocal privileges for U.S. citizens and citizens of selected foreigu countries, and some federal legislation extends specific favored treatment to particular nationalities independent of treaties. If these distinctions are not defined in terms of race and are not motivated by racial prejudice ... then they would not elicit heightened scrutiny under ordinary equal protection analysis.

Gerald Neuman, Terrorism, Selective Deportation and the First Amendment after Reno v. $A A D C, 14$ Geo. lmmig. L.J. 313, 339-40 (2000). See also Reno v. American-Arab AntiDiscrimination Committee, 525 U.S. 471, 488 (1999) (stating that generally "an alien unlawfully in this country has no constitutional right to assert selective enforcement as a defense against his deportation").

25. 481 U.S. 604,614 (1987). 
interview list that is dominated by Middle Eastern men, which raises the specter of ethnic profiling. To critics, Mr. Chertoff could as well have said "we have emphatically rejected age discrimination. What we have looked to are characteristics like date of issuance of birth certificate." Of course, no one much cares that the Department may be profiling by age and sex as well as by ethnicity.

Why did Mr. Chertoff insist on this distinction? He had no choice. Ten months earlier, Mr. Chertoff's boss, Attorney General John Ashcroft, declared that " $[t]$ here should be no loopholes or safe harbors for racial profiling. Official discrimination of this sort is wrong and unconstitutional no matter what the context." 26 To admit that the government made investigative choices based on race or ethnicity seems to admit racial profiling, which has been defined as so odious that there is no defense. In fact, racial profiling deserves its bad name. There is no justification, for example, for the infamous racial profiling by the Maryland and New Jersey state police on I-95, who stopped and searched thousands of minority motorists in search of drug traffickers, ${ }^{27}$ nor for similar drug interdiction practices by other police forces across the country. ${ }^{28}$ The activists and lawyers who made racial profiling a household word deserve a great deal of credit for dragging this practice into the light and mobilizing opposition to it. One result, however, has been to reduce the debate to a single point. When critics charge: "They're relying on race," the cops can only reply: "We are not."

But is the Justice Department's interview program ethnic profiling? The answer is not clear even assuming that ethnicity was a central factor in the selection of subjects. By our definition, it is not ethnic profiling for officers to focus their attention on people of a given ethnicity because the police have information that the specific crime they are investigating was committed by someone of that ethnic group. There is plenty of information that Middle Eastern men, some of whom remain at large, engaged in a conspiracy to commit acts of mass terror in the United States on September 11, 2001. Granted, the concept of a "specific crime" grows somewhat hazy when the crime at issue is an ongoing conspiracy of indeterminate size--and one that potentially involves not just Middle Eastern men,

26. Nomination of Senator John Ashcroft to the Office of Attorney General: Hearings Before the Senate Comm. on the Judiciary, 107th Cong. (Jan. 22, 2001) (answer from Senator Ashcroft, to written question submitted by Senator Russell D. Feingold), available at http://www.senate.gov/ leahy/press/200101/ashcroft.html (on file with the Columbia Law Review).

27. See State v. Soto, 734 A.2d 350, 352 (N.J. Super. Ct. Law Div. 1996) (focusing on traffic stops by New Jersey State Police); Samuel R. Gross \& Katherine Y. Barnes, Road Work: Racial Profiling and Drug Interdiction on the Highway 8-18 (Dec. 2001) (unpublished manuscript, on file with the Columbia Law Review).

28. Gary Webb, Cal. State Assembly Democratic Caucus Task Force on Gov't Oversight, Operation Pipeline (1999) (discussing racially disparate impacts of "Operation Pipeline" in California), available at http://aclunc.org/discrimination/webb-report.html (on file with the Columbia Law Review). 
but also others, from different racial or ethnic groups. Nevertheless, if the sole purpose for this interview program was to determine whether any of the thousands to be interviewed was involved in this conspiracy, or had information that might lead to those who were, this would not be ethnic profiling. (Which is not to say that such a broad brush investigation would be unproblematic; that's a different question, as we will see). On the other hand, the Justice Department's program would involve ethnic profiling if it was undertaken even in part based upon a general belief that Middle Eastern men are more likely to commit acts of terrorism than people of other ethnic groups-if it was based upon a global assumption about the criminal propensities of people of Middle Eastern descent. In practice, it is probably impossible to make that distinction in a case like this, involving the protracted investigation of a far-flung conspiracy.

\section{B. Is Race (or Ethnicity) a Strong Predictor of Criminal Behavior?}

On Sunday, February 28, 1999, Colonel Carl Williams of the New Jersey State Police told a reporter:

Today with this drug problem, the drug problem is cocaine or marijuana. lt is most likely a minority group that's involved with that. . . If you're looking at the methamphetamine market, that seems to be controlled by motorcycle gangs, which are basically predominantly white. If you're looking at heroin and stuff like that, your involvement there is more or less Jamaicans. ${ }^{29}$

Colonel Williams also said: "As far as racial profiling is concerned, that is absolutely not right. It never has been condoned in the State Police and it never will be condoned in the State Police."30 Nonetheless, several hours later, still on Sunday, Governor Christine Todd Whitman fired him from his job as superintendent of the New Jersey State Police because his comments, in her words, were "inconsistent with our efforts to enhance public confidence in the State Police." 31

At first blush, Colonel Williams seems to have done no more than restate the common law enforcement position that minority groups dominate major drug trafficking in the United States. ${ }^{32}$ Supporters have described him as an honest cop who was fired for telling the unpleasant, politically incorrect truth. ${ }^{33}$ His specific claims may be debatable; be-

29. Kathy Barrett Carter \& Ron Marsico, Whitman Fires Chief of State Police, Star Ledger, Mar. 1, 1999, at Al.

30. Id.

31. Id.

32. See, e.g., National Narcotics Intelligence Consumers Committee (NN1CC), The NNICC Report 1997, The Supply of Illicit Drugs to the United States 11-12 (Nov. 1998) ("Colombia-based traffickers continued to control wholesale level cocaine distribution throughout the heavily populated northeastern United States . . . often employing Dominican criminals as subordinates. . . In major U.S. cities, organized criminal groups of Cuban, Jamaican, and Mexican nationals, as well as African-American and ethnic Dominican gangs, dominated the retail market.").

33. Heather MacDonald, The Myth of Racial Profiling, City J., Spring 2001, at 14, 26. 
cause drug dealing is not a victim reported crime, we know little about the many drug dealers who are never caught. But there is little doubt about racial differences in other crime rates for which we have more reliable data. For instance, victim reports and arrest statistics both show that African Americans, who constituted roughly $13 \%$ of the population, committed over $40 \%$ of the robberies in the United States in $1999,{ }^{34}$ and about half of the homicides. ${ }^{35}$ When the New York City Police Department cited similar statistics in response to charges of racial profiling, ${ }^{36}$ their argument was a denial: "We don't target by race, we arrest those who should be arrested; it is unfortunate that many of them are black and Hispanic, but this is not our fault."

But Colonel Williams's comments could also be interpreted in a somewhat different manner, as a defense of racial profiling: "Of course we stop and search motorists based on their race-because it works. So cut us some slack." Seen in this light, his firing may not have been entirely unprincipled (especially since, despite his disclaimers, Colonel Williams seems to have resisted efforts to investigate racial profiling in his own department) ${ }^{37}$ Of course he did not say that racial profiling is justified, but didn't he imply it? In the political climate of 1999, a police commander could hardly defend racial profiling directly. The closest he could come is to say ambiguously that blacks and Hispanics do in fact commit most of the crimes that matter, and wink.

Before September 11, 2001, a few conservative commentators were the only people who publicly defended racial profiling on practical grounds. ${ }^{38}$ That has changed. Journalists, politicians, and pollsters have all expressed and documented a widespread sentiment that in order to win the "war on terrorism" we must focus our scrutiny on Middle Eastern Muslim men. ${ }^{39}$ The Justice Department's interview program may not be expressly aimed at such individuals, but it has this effect. It is explicitly aimed at individuals from Middle Eastern countries and other countries with an al Qaeda presence-and for good reason. Although other groups and individuals have committed terrorist acts in the United States,

34. Bureau of Justice Statistics, U.S. Dep't of Justice, Criminal Victimization in the United States, 1999 Statistical Tables tbls.40, 46 (2001), available at http://www.ojp.usdoj. gov/bjs/pub/pdf/crus99.pdf (on file with the Columbia Law Review).

35. Bureau of Justice Statistics, U.S. Dep't of Justice, Sourcebook of Criminal Justice Statistics 2000, at 316 tbl.3.150, available at http://www.albany.edu/sourcebook/1995/ pdf/section3.pdf (last visited Apr. 22, 2002) (on file with the Columbia Law Review).

36. See supra note 21 and accompanying text.

37. See Gross \& Barnes, supra note 27, at 4-5.

38. See, e.g., John Derbyshire, In Defense of Racial Profiling: Where is Our Common Sense?, Nat'l Rev., Feb. 19, 2001, at 38, 39 (arguing that police rely on racial stereotypes "for reasons of simple efficiency"); MacDonald, supra note 33, at 15-20 (arguing that racial profiling is a minor problem at worst and that it is legitimate for the police to make investigative choices based on race in conjunction with other factors).

39. See supra notes 2-3; see also Editorial, Terrorist Profiling: Behaviors are Important Clues, Dallas Morning News, Sept. 24, 2001, at 14A (noting scrutiny of Middle Eastern men after September 11, 2001). 
before September 11 and probably after, it is very likely true that al Qaeda, an organization that consists entirely of Muslim men, primarily from the Middle East, poses the greatest immediate threat of mass terrorist killings.

Fortunately, it is also no doubt true that only a tiny proportion of Middle Eastern men are affiliated with al Qaeda. A similar pattern can occur in other settings: Even if race or ethnicity is a strong predictor of criminal behavior, an individual member of the relevant groups is very unlikely to be a criminal. For example, it could simultaneously be true that $90 \%$ of major cocaine traffickers on $\mathrm{I}-95$ are black and Hispanic, ${ }^{40}$ and that $99.9 \%$ of black and Hispanic motorists on that highway are not drug traffickers of any description. When this type of juxtaposition does occur-and we rarely, if ever, have information this definitive-choosing suspects by race will increase the efficiency of the police. But the benefit to law enforcement may be slight, and it will come at a price that may be very steep, depending on the other factors we consider.

\section{What Does the Government Do Based on Race or Ethnicity?}

Southeastern Michigan has the largest concentration of Arab Americans and Near Eastern visitors in the country, perhaps 300,000 or more, including 521 of the 600 or so Michigan residents on the Justice Department's initial interview list. ${ }^{41}$ These subjects were contacted by letters from the local United States Attorney that said:

Your name was brought to our attention because, among other things, you came to Michigan on a visa from a country where there are groups that support, advocate, or finance international terrorism. We have no reason to believe that you are, in any way, associated with terrorist activities. Nevertheless, you may know something that could be helpful in our efforts. ${ }^{42}$

They were then asked to call the United States Attorney's office by a given date to set up an appointment for an interview. ${ }^{43}$

In a national poll in late November $2001,79 \%$ of respondents said that they approve of this program. ${ }^{44}$ Two years earlier, as we have men-

40. Gross \& Barnes, supra note 27 , at 57 tbl.18.

41. Telephone Interview with John Bell, supra note 22; see also Naftali Bendavid, Interview Letters go to 500 in Michigan, Chi. Trib., Nov. 27, 2001, $\$$ I, at 1 (noting that federal officials sought to interview over 500 Middle Eastern men in Michigan); Lengel, supra note 14 .

42. Letter from Jeffrey Collins, U.S. Att'y, E.D. Mich. and Robert P. Cares, Asst. U.S. Att'y, E.D. Mich. (Nov. 26, 2001) [hereinafter Letter] (emphasis omitted) (on file with the Columbia Law Review); see also Lengel, supra note 14 (publishing text from letter used by U.S. Attorney's office).

43. Letter, supra note 42.

44. Richard Morin \& Claudia Deane, Most Americans Back U.S. Tactics; Poll Finds Little Worry Over Rights, Wash. Post, Nov. 29, 2001, at Al; Roper Data Base, supra note 1 (describing results from ABC News, Wash. Post Poll, Nov. 27, 2001, question 18, accession \#0392049). 
tioned, $81 \%$ said they disapproved of "racial profiling." 45 Much of the change was a reaction to the September 11 attacks, an issue we address below, but the high level of support for the Justice Department's plan may also reflect the nature of the investigation, at least as initially presented.

The interviews are described as purely voluntary, though that is something of an exaggeration. The constitutional regulation of stops and searches is based in part on the premise that the average citizen feels free to ignore an armed police officer who asks for identification, or to look in the trunk, and that the nearly universal compliance with such demands is voluntary. ${ }^{46}$ This is a convenient fiction even under ordinary circumstances, let alone in this context. The typical recipient of one of these letters-a foreign student on a temporary visa from a country with an authoritarian and sometimes abusive government-must be forgiven if he interprets the request for an interview as an order. Worse, he may be right to do so. An lmmigration and Naturalization Service memorandum that has been publicized in the press suggests that some of those interviewed might be detained without bond if the "investigators [develop] an interest in them. "47 A lot turns on how this investigation is actually carried out, a point we will return to. For now, let us suppose the government conducts a program that is as voluntary and respectful as possible.

Assuming for the moment that the Justice Department's investigation does rely on ethnic profiling, this is not the racial or ethnic profiling we are used to hearing about. That would be more like the following: Put a list of the license plate numbers of cars driven by Middle Eastern men on a law enforcement computer network and ask local police officers to look out for them, pull them over if they see them, search their cars on any plausible pretext, and arrest them on any possible charge. Both programs use ethnic information to identify their subjects. The difference, and it is vast, is what the government does to those people once they have been identified.

Perhaps the worst instance of ethnic profiling in American history began on February 19, 1942, when President Franklin Delano Roosevelt signed Executive Order $9066,{ }^{48}$ giving the Secretary of War the power to order over 110,000 Japanese Americans on the west coast to be "resettle [d]" in "relocation centers" for the duration of the war. ${ }^{49}$ The Japanese internment was a disgraceful episode in American history. 1t is fre-

45. See supra note 1 and accompanying text.

46. See, e.g., Florida v. Bostick, 501 U.S. 429, 434 (1991) (noting that "mere police questioning does not constitute a seizure"). For an extended doctrinal discussion of this issue, see David Cole, No Equal Justice: Race and Class in the American Criminal Justice System 27-34 (1999).

47. The Questioning: Memo Adds to Suspicions of Immigrants on Interviews, N.Y. Times, Nov. 29, 2001, at B6.

48. Exec. Order No. 9066, 3 C.F.R. 1092 (1938-1943).

49. See Greg Robinson, By Order of the President: FDR and the Internment of Japanese Americans 127-28, 130-31 (2001). 
quently cited as the prime example of the evil things we might do if we pursue racial profiling in response to the attacks of September $11 .^{50} \mathrm{But}$ what if, instead of being forced to sell their property for pennies on the dollar, to leave their homes, schools, farms, jobs, and communities, and to spend three and a half years behind barbed wire, Japanese Americans had been asked to report for interviews with the FBI? What if in addition they were required-because of their ethnicity-to report their whereabouts to the police periodically, but were otherwise allowed to lead their lives as they wished? Perhaps these policies, especially the second, would also have been unjustified, even during an all out war. Certainly both programs-like the actual internment program-would have involved ethnic profiling. Under any name, however, these sorts of ethnic profiling would have been far preferable to the relocation and imprisonment that were in fact ordered.

The range of things the government can do on the basis of racial or ethnic information is enormous. If mass imprisonment defines the high end (short of torture or execution), paying close attention may define the low end. After September 11, nobody could seriously complain about the FBI paying more attention to reports of suspicious behavior by Saudi men than to similar reports about Hungarian women-even though as a consequence many more Saudi men will set off false alarms. In between there are infinite gradations, as the government's conduct becomes increasingly intrusive, disruptive, frightening, and humiliating. There are, however, two important questions that cut across this terrain.

The first separates out a class of cases near the bottom of the slope: Did the investigators impinge on the suspect by confronting him, or by covertly invading his privacy? If not-if, in the clearest case, the authorities did no more than gather information at a distance, from public sources-the worst consequences will be minimal. More often than not, the suspect will never know. We do not mean to say that such activities are therefore justified. A fascinating recent study, for example, analyzed computer traffic from police cruisers in a predominantly white suburban town and found that the officers were more likely to run license-plate checks on cars with black drivers than on cars with white drivers, and increasingly so the farther they were from the border of the neighboring, black-dominated metropolis. ${ }^{51}$ The only good thing we can say about the profiling in that case is that few of its victims ever realized their status.

The second question is more important because it affects the experience of people who do know what is being done to them: Is the subject treated as one of us or as one of them, as a law abiding person to be checked out or as a criminal to be caught and punished? Security check-

50. See, e.g., Leanora Minai, Cops Target Local Mideast Men, St. Petersburg Times, Nov. 28, 2001, at A1.

51. Albert J. Meehan \& Michael Ponder, Race and Place: The Ecology of Racial Profiling African-American Motorists 10-11 (2001) (unpublished manuscript, on file with the Columbia Law Review). 
points are democratic; everybody must go through them, so no stigma is attached to the process. Some people these days get angry if they are not checked carefully enough, ${ }^{52}$ but even those who are asked to open their bags or scanned by hand are treated essentially like ordinary members of the public. The operating assumption for any individual, Muslim or Presbyterian, is that she will clear security and rejoin the crowd. On the other hand, a passenger who is kicked off an airliner (for good reasons or bad) is treated as a presumptive terrorist. Not only are his plans disrupted, but he is singled out and humiliated in public.

The paradigmatic context for racial profiling-the setting in which the term was coined-is drug interdiction on the highway. ${ }^{53}$ From the point of view of the state trooper, a motorist who is stopped and searched is a potential catch, a shot at a big, career building drug bust. But most of those who are searched are totally innocent, and from their viewpoint the process looks and feels very different. You are stopped for a minor or nonexistent traffic violation; the officer scrutinizes your car carefully through the window and then tells you to step outside; he asks you pointed questions about your trip, your plans, your companions, your friends, and perhaps expresses doubts about the honesty of your answers; he asks for permission to search the car; if you agree, he rummages through your vehicle and belongings; if you refuse, he calls for backup and a police dog to sniff your car for drugs. ${ }^{54}$ Long before that point, however, you realize that you've been targeted. The trooper is not going through a routine so he can let you go on your way and move on to his next task. He believes you are a drug dealer; he wants to find drugs on you. He wants to prove that you are a criminal, preferably a big criminal, and will be disappointed if he finds no drugs; he might get mad.

52. See generally John Reid Blackwell, Flights Mostly On Schedule; Screening Steps Largely Invisible, Richmond Times-Dispatch, Jan. 19, 2002, at A1 (illustrating the positive reaction of passengers subjected to increased airport security measures); All Things Considered, Analysis: Increased Security for U.S. Airlines (NPR radio broadcast, Jan. 18, 2002), available at 2002 WL 3494730 (reporting positive reactions of passengers subjected to increased airport security measures).

53. A search of the LEXIS All News file reveals that the first use of the terms "racial profile" or "racial profiling" in a published news article on any aspect of law enforcement was in a February 1990 story about drug interdiction by the New Jersey state police. Joseph F. Sullivan, New Jersey Police are Accused of Minority Arrest Campaigns, N.Y. Times, Feb. 19,1990 , at B3. The first use of either of these terms in a published court opinion is in United States v. Whren, 53 F.3d 371, 373 (D.C. Cir. 1995), aff'd, 517 U.S. 806 (1996) (concerning drug interdiction in a city), but several earlier opinions on highway drug interdiction refer to "race-based profiles" or the use of race in "drug courier profiles." See, e.g., United States v. Laymon, 730 F. Supp. 332, 337 (D. Colo. 1990) (detailing the use of "'profiling' based on race" by a county drug task force); Lowery v. Commonwealth, 388 S.E.2d 265, 268 (Va. Ct. App. 1990) (concluding that "the officer had adequate justification, independent of the profile using race as a factor, to stop the defendant's vehicle").

54. See, e.g., Webb, supra note 28 (describing stop and search procedures for the California Highway Patrol); Angela J. Davis, Race, Cops, and Traffic Stops, 51 U. Miami L. Rev. 425, 438-40 (1997) (describing a stop by Maryland State Police). 
Those of us who have not been through this sort of experience probably underestimate its impact. ${ }^{55}$ To be treated as a criminal is a basic insult to a person's self image and to his position in society. 1t cannot easily be shrugged off. Of course, many victims of racial profiling are not surprised by this treatment. They know why they were stopped-which makes it worse. 1t's bad enough to have the accidental misfortune of being mistaken for a bad guy; it's worse to feel that you are assumed to be a criminal because of your race. Short of imprisonment, intimidation, or physical abuse, most of the pain of racial profiling is caused by treating law abiding people like criminals. ${ }^{56}$

\section{How Strong Is the Evidence of a Racially Identified Suspect's Guilt or Innocence?}

Our normal operating assumption about racial profiling is that the typical individual who is profiled is very unlikely to be guilty. (Certainly no more than a tiny proportion of the men interviewed by the FB1 are members of al Qaeda, if any.) The less likely the guilt of any individual, the higher the proportion of innocent people among those affected, and the higher the social cost of the practice. But what if the evidence of individual guilt becomes much stronger? Would this change our view on the use of profiling? The New York City Police Department's anti-gun campaign is a good illustration. From January 1998 through March 1999, guns were found on only $2.5 \%$ of the nearly 60,000 people who were stopped for suspected gun possession-one person in 40.57 Assuming the police did use race to decide whom to stop and frisk, would we feel differently about the practice if they had found weapons on $90 \%$ of those they searched? How about $30 \%$ ?

55. On May 8, 1992, Robert Wilkins, an African American lawyer who at the time worked at the District of Columbia Public Defender Service, was driving from Chicago to Washington, D.C. with several family members on a trip to his grandfather's funeral. They were stopped by a Maryland State Police trooper in an instance of racial profiling that triggered a major lawsuit against the Maryland State Police. Eight years later, Mr. Wilkins described the experience in testimony before the United States Senate:

So there we were. Standing outside the car in the rain, lined up along the road, with police lights flashing, officers standing guard, and a German Shepherd jumping on top of, underneath, and sniffing every inch of our vehicle. We were criminal suspects; yet we were just trying to use the interstate highway to travel from our homes to a funeral. It is hard to describe the frustration and pain you feel when people presume you to be guilty for no good reason and you know that you are innocent.

Racial Profiling Within Law Enforcement Agencies: Hearing Before the Subcomm. on the Constitution, Federalism, and Property Rights of the Senate Comm. on the Judiciary, 106th Cong. 19 (2000) (statement of Robert L. Wilkins).

56. For a thoughtful discussion of one of the implications of this point-namely, that even if racial profiling proves impossible to root out entirely, much of the harm it inflicts could be ameliorated by better, more respectful treatment of those the police target-see William J. Stuntz, Local Policing After the Terror, 111 Yale L.J. (forthcoming June 2002).

57. OAG Report, supra note 19, at 118 tbl.1.B.3. 
If racial profiling in the near absence of evidence of an individual suspect's guilt represents one end of the spectrum, the other end exists only in theory. Imagine a suspect who is found standing over a dead body holding a smoking gun. What if the first officer on the scene admits that he arrested the suspect because of his race, as well as the obvious nonracial reasons? If this unlikely hypothetical came to life, we'd condemn that officer's racism; we might want to have him disciplined; but we probably would not think that the defendant is entitled to be released. Courts that say that under the Fourth Amendment race may be considered in a profile as one factor among several ${ }^{58}$ may have this issue in mind. The more factors the officer considers-the more information he uses-the more likely it is that he is accurate in his suspicion. But these cases present a different situation from the one in our smoking gun hypothetical. In our hypothetical, race was not a necessary cause of the arrest: Obviously the suspect would have been arrested anyway by an officer who did not rely on race. In the usual Fourth Amendment profiling case, race is a necessary element in the profile, along with others; the suspect is stopped because he is black and male, young, out after dark, driving a sports car, etc. The use of other factors of this sort is inevitahle-even the most committed racial profiler does not choose suspects at random from an entire racial group-but they do not point to an individual who is uniquely likely to be guilty.

A suspect's race alone is never strong evidence of guilt. There is no serious crime that is committed by all, or most, or even a large fraction of the members of any racial group. ${ }^{59}$ But race together with other information about the suspect can form a pattern that is persuasive to any degree. The usual situation does not involve profiling but case specific information. If reliable witnesses report that they saw a white man running from the scene of a murder and going into a bar in which there are only three white men, the police have enough information to detain all three-"reasonable suspicion"-and they might have probable cause to arrest them as well. If there is only one white man in the bar, there might just be enough to convict by proof beyond a reasonable doubt.

While a suspect's race alone is never proof of guilt, a suspect's race is frequently powerful evidence of innocence. If the eyewitnesses to a murder are right and the killer was a white man, that is conclusive evidence of the innocence of any person who is black, or a woman. (The witnesses could in theory be mistaken, but even so the police are justified in treating their description as very strong evidence of innocence of any person of the wrong race or sex.) This may be the real reason why courts uniformly agree that police officers may rely on racially specific descriptions

58. See supra notes 7-8 and accompanying text.

59. On the other hand, there are some minor offenses, such as speeding on the highway, that virtually everyone commits, regardless of race. See, e.g., State v. Soto, 734 A.2d 350, 352-53 (N.J. Super. Ct. Law Div. 1996) (citing statistical study of traffic violations by race); Gross \& Barnes, supra note 27, at 38-39. 
of criminal suspects, despite the prohibition against the use of racial classifications. ${ }^{60}$ Some courts explain this rule by saying that this is not a "racial classification" for Fourteenth Amendment purposes, but that, of course, begs the question. ${ }^{61}$ This is a racial classification as that phrase is used in ordinary language; if it is not a racial classification under the Fourteenth Amendment, this is simply because the relevant court is prepared to say that this use of race is legal. lt might be more informative to say that the state has a compelling interest in not investigating people for crimes when they are known to be innocent because it is wasteful, irrational, and profoundly unjust to do so.

\section{E. What are the Likely Benefits of Racial Profiling?}

The post-September 11 change in climate on civil liberties has a single cause: mass murder by organized foreign terrorists. We've seen it done, spectacularly, on live TV. 1t's an old point: The greater the threat, the more we are willing to accept restrictions on our liberty, and the less precision we demand from the government in response. Justice Robert Jackson's dissent in Brinegar $v$. United States may still be the most widely cited statement of this position, at least in the Fourth Amendment context:

If . . a child is kidnaped and the officers throw a roadblock about the neighborhood and search every outgoing car, it would be a drastic and undiscriminating use of the search. The officers might be unable to show probable cause for searching any particular car. However, I should candidly strive hard to sustain such an action, executed fairly and in good faith, because it might be reasonable to subject travelers to that indignity if it was the only way to save a threatened life and detect a vicious crime. But I should not strain to sustain such a roadblock and universal search to salvage a few bottles of bourbon and catch a bootlegger. ${ }^{62}$

The point was recently echoed by the Supreme Court in Florida v. J.L. ${ }^{63}$ There, in holding that an anonymous tip that a person is carrying a gun is not, without more, sufficient to justify a stop and frisk, Justice Ruth Bader Ginsburg took pains to note:

60. See R. Richard Banks, Race-Based Suspect Selection and Colorblind Equal Protection Doctrine and Discourse, 48 UCLA L. Rev. 1075, 1083-88 (2001) (discussing scholarly views and judicial analyses of race-based suspect selection); Sheri Lynn Johnson, Race and the Decision to Detain a Suspect, 93 Yale L.J. 214, 237-43 (1983) (describing constraints on the use of racial classifications in criminal proceedings).

61. See, e.g., Brown v. City of Oneonta, 221 F.3d 329, 336-39 (2d Cir. 2000) (asserting that police wbo stopped and questioned African American plaintiffs based on a victim's physical description of the perpetrator "did not engage in a suspect racial classification that would draw strict scrutiny").

62. 338 U.S. 160,183 (1949).

63. 529 U.S. $266(2000)$. 
The facts of this case do not require us to speculate about the circumstances under which the danger alleged in an anonymous tip might be so great as to justify a search even without a showing of reliability. We do not say, for example, that a report of a person carrying a bomb need bear the indicia of reliability we demand for a report of a person carrying a firearm before the police can constitutionally conduct a frisk. ${ }^{64}$

How does this apply to racial profiling? If we thought we could reduce the risk of hijacking by $15 \%$, would that justify searching every Middle Eastern man who boards a plane? This may well be within the current national consensus that we must take strong measures to protect ourselves. On the other hand, the same people who would accept severe measures (including ones based on race) that offered any promise of reducing a genuine threat of nuclear terrorism, might still readily condemn a racial profiling program that efficiently combats the threat of marijuana possession or ticket scalping. And even people who favor the Justice Department's post-September 11 interview program might be angry if the Department sent out letters to 5000 Mexican nationals, almost all of them law abiding, asking them to come in for interviews because:

Your name was brought to our attention because, among other things, you came to the United States on a visa from a country where there are groups that engage in or finance international drug trafficking. We have no reason to believe that you are, in any way, associated with drug trafficking. Nevertheless, you may know something that could be helpful in our efforts.

There are two parts to this calculation: How great is the harm we are fighting? And how likely is our conduct to be useful? When the danger is extreme, we may accept unpleasant methods that have only a slight chance of success. But it is one thing to sketch out these calculations on paper, and quite another to do so in a real emergency. We never actually know either the magnitude of the danger or the effectiveness of possible countermeasures. Urgency and fear do not improve our judgment. They may lead us to overestimate the danger, or the value of preventive steps, or both. Racism and ethnic prejudice may color every step of the process. Most Americans probably feel particularly threatened because the September 11 suicide hijackers were foreign, and some may be especially fearful because they were Arabs. This fear may cause us to exaggerate the danger of future attacks in general, and of attacks by Middle Eastern terrorists in particular. As a result, we may overestimate the effect of racially specific security measures. And unfortunately, we are more willing to accept aggressive measures when they target small and politically disempowered groups, specifically racial and ethnic minorities, and foreign nationals. 
III.

Applying this scheme to several concrete examples helps place racial profiling in the context of other police practices that take race or ethnicity into account. The illustrations that we use range from clear instances of racial profiling, to ambiguous situations, to cases that do not fit the definition of racial profiling but are equally disturbing all the same. When we consider them in light of the entire set of factors we have discussed, we see that the appropriateness of a particular law enforcement practice turns on a more complicated assessment than whether the label "racial profiling" properly applies.

Highway Drug Stops. The archetypal example of racial profiling is the practice that gave rise to the phrase "Driving While Black": racial profiling in traffic stops in general, and as an aspect of highway drug interdiction in particular. This is an easy case. There is overwhelming evidence that the police do rely on race to decide whom to stop and to search. ${ }^{65}$ Law enforcement sources frequently claim that drug trafficking in the United States is dominated by blacks and Hispanics; but there is little doubt that the drug culture in this country is general, and that the great majority of illicit drug users are white. ${ }^{66}$ The treatment of suspects who are profiled is heavy handed and humiliating. ${ }^{67}$ The probability of guilt for any individual who is stopped is low; few are carrying any drugs at all, and only a tiny proportion are drug traffickers. ${ }^{68}$ Finally, racial profiling on the highway produces no discernible benefits. The entire war on drugs is fraught with ambiguity and ambivalence, and many commentators have concluded that the effort to reduce drug consumption by limiting supply is doomed to failure. ${ }^{69}$ We need not reach this question, however, because the specific program at issue is ineffective by any standard. Fishing for drug couriers in the immense stream of cars on interstate highways is a hopeless strategy for eliminating drug trafficking; it probably has no impact whatsoever on drug markets. ${ }^{70}$ It should be no surprise that racial profiling on the highway is almost uniformly condemned.

Gun Searches. The New York City Police Department's anti-gun campaign is a harder case. ${ }^{71}$ The evidence that the police used race to decide whom to stop and frisk for weapons is less clear than the evidence that state police officers do so for highway stops, but let us assume that they

65. See supra notes $27-28$ and accompanying text.

66. See Dep't of Health and Human Serv., Summary of Findings from the 2000 National Household Survey on Drug Abuse 21-22 (Sept. 2001), available at http://www. samhsa.gov/oas/NHSDA/2kNHSDA.pdf (on file with the Columbia Law Review).

67. See supra note 54 and accompanying text.

68. Gross \& Barnes, supra note 27, at 56.

69. See Steven B. Duke \& Albert C. Gross, America's Longest War 203-07 (1993); Ethan A. Nadelmann, The Case for Legalization, in The Crisis in Drug Prohibition 13, 21 (1990); Samuel Walker, Sense and Nonsense about Crime and Drugs 262 (3d ed. 1994).

70. Gross \& Barnes, supra note 27, at 106-09.

71. See supra note 19 and accompanying text. 
did. Let us also assume that the police are correct in their claim that blacks and Hispanics were much more likely than whites to carry guns. The treatment of profiled suspects was coercive, humiliating, and sometimes violent, and yet only a small minority-one in 40-were actually found to be carrying guns. On the other side of the ledger, the benefits of this campaign may have been substantial. The murder and violent crime rate decreased sharply in the mid-1990s, and at least some of the drop may have been due to this effort. ${ }^{72}$ Nonetheless, we believe that racial profiling, if it occurred, cannot be justified on practical or legal grounds. The cost was very high-dozens of thousands of unarmed young men stopped and searched in public, ${ }^{73}$ an ugly crisis in relations between the Police Department and minority communities ${ }^{74}$-and the benefits speculative. The status quo in 1994 was serious, but judging from patterns in other cities, it is fairly clear that crime would have dropped to some extent regardless of police practices; ${ }^{75}$ and we have no idea whether less troubling methods would have succeeded as well or better.

Racial Incongruity. In some contexts, an individual's race may provide a substantial basis for suspicion even in the absence of information about any specific criminal activity. In the classic case, the police justify the stop of a white person in a neighborhood where the great majority of residents are black or Hispanic on the ground that virtually all white people who go to that neighborhood do so to buy drugs. As a factual matter, the police may be right; in a few cases, courts have accepted their judgment and upheld the stops. ${ }^{76}$ Most courts, however, have held that such stops are unconstitutional because being racially "out of place" does not

72. See Jeffrey Fagan et al., Declining Homicide in New York City: A Tale of Two Trends, 88 J. Crim. L. \& Criminology 1277, 1313-18 (1998) (concluding that policing may have caused or helped cause drop in gun related homicides); see also David Garland, Criminology, Crime Control, and "The American Difference," 69 U. Colo. L. Rev. 1137, 1150 (1998) (arguing that street stops and searches discourage casual gun possession and thus reduce the potential violence of unplanned street incidents).

73. See supra note 19 and accompanying text.

74. See Jeffrey Fagan \& Garth Davies, Street Stops and Broken Windows: Terry, Race, and Disorder in New York City, 28 Fordham Urb. L.J. 457, 462 (2000); Jerome H. Skolnick \& Abigail Caplovitz, Guns, Drugs, and Profiling: Ways to Target Guns and Minimize Racial Profiling, 43 Ariz. L. Rev. 413, 415-17 (2001).

75. See Fox Butterfield, Cities Reduce Crime and Conflict Without New York-Style Hardball, N.Y. Times, Mar. 4, 2000, at Al.

76. See, e.g., State v. Dean, 543 P.2d 425, 427 (Ariz. 1975) (noting fact that when a person is observed in a neighborhood not frequented by persons of his ethnic background it "is quite often a basis for an officer's initial suspicion"); State v. Ruiz, 504 P.2d 1307, 1310 (Ariz. Ct. App. 1973) (holding that officers were justified in stopping a person based on police testimony that it was "unusual to see a person of either "white' or Mexican descent" in the area and that the few people police had noticed in the past "were there for the purpose of purchasing narcotics"); cf. United States v. Magda, 409 F. Supp. 734, 740 (S.D.N.Y. 1976), rev'd, 547 F.2d 756, 759 (2d Cir. 1976) (reversing trial court that had suppressed evidence where defendant was stopped entirely because he participated in an interracial interaction in "narcotics-prone" area). 
create a reasonable suspicion of criminal activity-notwithstanding that the officers' conduct is ostensibly based on localized assessments of the significance of race in particular settings, rather than on global assessments about the propensities of a racial or ethnic group. ${ }^{77} \mathrm{~A}$ better explanation for these decisions might be that arresting occasional drug users and retail dealers is not a sufficient benefit to justify stopping and searching people who cross common lines of residential and social segregation, even if the factual premise is correct. Indeed, our interest in ending racial segregation is so strong that there may be no circumstances in which social integration should be considered a proper basis for suspicion of criminality. ${ }^{78}$

Underworld Segregation. A suspect's race, together with other factors, might also provide strong grounds for suspicion in another setting: investigation of a segregated criminal organization. Suppose that the FBI is investigating the activities of the Gambino crime family, an organization whose membership consists almost entirely of men of Sicilian descent. Agents hear from a reliable informant that a meeting is to take place between a known Gambino capo and another, unknown crime family member. Wiretap information confirms that the purpose of the meeting is a payoff for a hit. Agents set up physical surveillance at the meeting site-a park in the Bensonhurst section of Queens, New York-but fail to spot the known crime family member. They then see two other men walk by, an African American and someone who seems to be Italian American. If the agents ignore the African American and focus their attention on the Italian American, are they engaged in racial profiling? Like the Justice Department's interview program, this case defies categorization. ${ }^{79}$ The agents may be following up on case-specific information that the perpetrators of a specific crime-namely, conspiracy to murder-are Sicilian, but they may also be relying on a global assessment that Sicilians are more likely to be involved in this sort of organized crime. In context, of course, the distinction makes little difference. Either way, the agents'

77. See, e.g., People v. Bower, 597 P.2d 115, 119 (Cal. 1979) (stating that “[a] person's racial status is not an 'unusual' circumstance and the presence of an individual of one race in an area inhabited primarily by members of another race is not a sufficient basis to suggest that crime is afoot"); State v. Letts, 603 A.2d 562, 566 (N.J. Super. Ct. Law Div. 1992) (stating that the state cannot view a person's race as indicative of probable criminal activity); State v. Kuhn, 517 A.2d 162, 165 (N.J. Super. Ct. App. Div. 1986) (declaring that " $[\mathrm{n}]$ o rational inference may be drawn from the race of one to be detained that he may be engaged in criminal activities").

78. A common example of racial profiling that is directed at those who are seen as racially "out of place" is the practice in some police departments of stopping minorities who cross into well-to-do white communities. See Meehan \& Ponder, supra note 51, at 2-3, 18-19. Stops of this sort are particularly troubling because they have the effectsometimes, no doubt, the intended effect-of reinforcing racial segregation.

79. Professor Richard Banks describes this situation as a case of racial profiling, but one that is less disturbing than the common one because it does not embody a broad stereotype about the criminal propensities of a racial group, and therefore is less stigmatizing and objectionable to the group concerned. Banks, supra note 60, at 1097-99. 
conduct is minimally intrusive (surveillance in a public place); and either way, if the man they follow leads them to the capo they will have more than enough information to arrest both men for conspiracy to commit murder, if they want to terminate the investigation at that point.

The Wen Ho Lee Case. Charges of racial profiling are usually addressed to ongoing law enforcement policies, but occasionally they have been directed at the investigation of a single matter. One of the most complex and ambiguous cases of this sort is the prosecution of Dr. Wen Ho Lee. ${ }^{80}$ Lee, a Taiwan-born naturalized citizen and a physicist at the Los Alamos National Laboratories, was suspected of providing nuclear secrets to the People's Republic of China. He was indicted for fifty-nine felony counts of violating the Atomic Energy Act and ten counts each of unlawfully obtaining and unlawfully retaining national defense information. He was suspected but not charged with espionage. Lee was arrested and held without bail in solitary confinement for nearly ten months, shackled whenever he was led out of his cell, and closely watched at all times, including family visits. Ultimately, Dr. Lee was released with an apology from the judge, and pled guilty to one felony count of violating nuclear security statutes, with a sentence of time already served. ${ }^{81} \mathrm{Dr}$. Lee has admitted illegally downloading secret data on nuclear weapons, but he has always denied spying for China.

One of the complaints about the Wen Ho Lee case is that the investigation was based on racial profiling. ${ }^{82}$ We don't know enough to say whether that is a plausible description, but let us assume that the case did not involve racial profiling as we define it. Let us assume, for example, that the FBl had reliable information that an American nuclear spy was in contact with Chinese intelligence, and that the person in question was fluent in Mandarin. ${ }^{83}$ Given that information, it would not have been racial profiling to confine the investigation to Chinese speaking suspects, since that restriction would have been based on information about the perpetrator of a particular crime rather than on a prediction about the criminal propensities of Chinese American scientists in general. We have no reason to believe that the FB1 had such information. Our point is that

80. United States v. Lee, No. CR 99-1417 JP (D.N.M. Aug. 31, 2000) (mem.), available at http://www.fas.org/irp/ops/ci/whl_release_opinion.html (on file with the Columbia Law Review); see also United States v. Lee, 90 F. Supp. 2d 1324 (D.N.M. 2000); United States v. Lee, 79 F. Supp. 2d 1280 (D.N.M. 1999).

81. Statement by Judge in Los Alamos Case, With Apology for Abuse of Power, N.Y. Times, Sept. 24, 2000, at A25.

82. Matthew Purdy, The Making of a Suspect: The Case of Wen Ho Lee, N.Y. Times, Feb. 4, 2001, at A1; Matthew Purdy \& James Sterngold, The Prosecution Unravels: The Case of Wen Ho Lee, N.Y. Times, Feb. 5, 2001, at A1.

83. This assumption may well be contrary to the facts. According to news reports, a classified Department of Justice report on the Wen Ho Le case criticizes the FBI investigators, among other things, for failing to consider the real possibility that no espionage had in fact occurred. Dan Eggen, Report Details More FBI Blunders in Wen Ho Lee Probe, Wash. Post, Aug. 27, 2001, at A1. 
this assumption would hardly change anything in the debate over Dr. Lee's case. His supporters would continue to argue that even if it was likely that some ethnically Chinese person committed espionage, there was little evidence that this Chinese American man was guilty-certainly no evidence that would have justified the harsh treatment he receivedand that the government's willingness to treat him as it did on so flimsy a basis reflected racism. On the other side, the government's defenders would continue to argue that the magnitude of the risk from nuclear espionage is so great that extreme measures are necessary to apprehend spies and to prevent them from communicating with their handlers once in custody. The factors that matter most are the quality of the evidence against Dr. Lee and the harshness of the treatment he received on the one hand, and the magnitude of the risk he may have posed on the other, rather than the usual profiling questions: Did the FB1 identify him by ethnicity? And are Chinese Americans more likely than the rest of us to spy for China?

The Oneonta Investigation. Another controversial investigation with racial overtones began at 2 a.m. on September 4, 1992, in the small town of Oneonta, New York, when someone broke into the house of a seventyseven year old woman, attacked her, and fled, all under cover of darkness. The victim described the assailant as a young black man with a knife, and told the police that he had cut his hand. ${ }^{84}$ Over the next several days the police located every black male student in the local college, questioned them, and inspected their hands for cuts. They then did the same for every other nonwhite man they could find, and at least one nonwhite woman-over 200 people in all. Their objective, according to the investigator in charge, was "to examine the hands of all the black people in the community." 85

The Second Circuit held that those stopped and questioned in Oneonta had no cause of action under the Equal Protection Clause because the police were acting on the victim's racial description rather than their own racial stereotypes or preferences. ${ }^{86}$ For the same reason, we would not classify this as a case of racial profiling. But the incident is disturbing all the same for reasons we have discussed: The police conducted an aggressive investigation, stopping and questioning hundreds of innocent people, with some unpleasantness along the way; they did so on the basis of extremely limited information; they were responding to a serious crime, but not an emergency. The police were criticized for doing some-

84. Brown v. City of Oneonta, 221 F.3d 329, 334 (2d Cir. 2000), reh'g en banc denied, 235 F.3d 769, 770 (2d Cir. 2000); see also Banks, supra note 60, at 1078-81 (providing extensive analysis of the case).

85. Brown, 235 F.3d at 780 (Calabresi, J., dissenting from denial of rehearing en banc) (internal quotation marks omitted).

86. Brown, 221 F.3d at 337-38. 
thing they would never have done if the criminal had been white. ${ }^{87}$ As the Second Circuit noted, this technique would be hopelessly ineffective for a white suspect because whites are a much larger group, the great majority of the population in Oneonta. ${ }^{88}$ But in operation it was equally ineffective for a black suspect, and it is hard to believe that the police would have considered treating the white residents of Oneonta in this humiliating manner in an attempt to solve a single burglary and assault, even if it were feasible. What is most striking from our point of view is that the problem with the Oneonta investigation was not its racial specificity but the number of innocent people affected, and the manner in which they were treated. If the police had stopped and questioned black men only but had confined themselves to those few who were in the vicinity near the time of the crime, or if they had asked the neighbors if they had seen any black men in the area, no one would have blinked.

\section{CONCLUSION}

To return to the Justice Department's program: Does the plan to interview thousands of Middle Eastern men who came here within the last two years on nonimmigrant visas constitute ethnic profiling? The answer turns out to be a draw. ${ }^{89}$ It is ethnic profiling to the extent that the FBI is operating on a general assumption that Middle Eastern men are more likely than others to commit acts of terror; it is not to the extent that the agents are pursuing case-specific information about the September 11 attacks, albeit in a dragnet fashion. In practice, we cannot separate or distinguish between these two conditions.

We also think that neither the question nor the answer is all-important. The Oneonta investigation was not racial profiling, but it was an offensive and unjustified use of race all the same; so are similar cases in which the police, acting on information that a particular criminal is a black man, proceed to stop, search, and perhaps arrest an innocent black man based solely on his race and sex. ${ }^{90}$ The Justice Department's program may or may not fall within our definitional line. Its wisdom and morality, however, do not depend on the pigeonhole in which it is placed but on what the Justice Department in fact does. Are the interviews conducted respectfully, in a manner designed to seek out relevant informa-

87. See, e.g., Editorial, Discriminatory Searches, N.Y. Times, Nov. 5, 1999, at A32 (stating that the Second Circuit panel "was apparently untroubled by the fact that this technique would never be used against whites"); Bob Herbert, Editorial, Breathing While Black, N.Y. Times, Nov. 4, 1999, at A29 (alleging that the police disregarded the rights and humanity of the black citizens of Oneonta because of their race).

88. Brown, 221 F.3d at 338.

89. See supra Part 1I.A.

90. See, e.g., Washington v. Lambert, 98 F.3d 1181, 1194 (9th Cir. 1996) (upholding verdict for two African American plaintiffs who had been stopped and searched solely on account of their race); Dinitia Smith, Actor Resumes Role After Ordeal, N.Y. Times, July 22, 1999, at B3 (describing erroneous arrest and strip search of an African American Broadway actor). 
tion from those who are willing to give it? If so, the program is acceptable; it may even be an example of good investigative work. On the other hand, if the "voluntary" character of these interviews is merely a ruse-if men against whom there is no evidence are treated as suspects and demeaned-then the program is an intolerable form of ethnic discrimination.

To be clear, whether the interviewees are "treated as suspects" involves more than the tone in which the interviews are conducted. Visa violations are very common, and many are ignored by the Immigration and Naturalization Service. Those who are interviewed, even if they are lawfully in the United States themselves, may well know of others who have committed immigration related offenses. In a worst case scenario, the interviewees could be asked general questions about infractions of which they are aware; for example: "Do you know of any other person who is in the United States on an invalid or expired visa?" Many would deny that they know of such violations, which would subject them to prosecution for making a false statement to a federal agent, ${ }^{91}$ which in turn would expose them to arrest, detention, felony prosecution, and possibly deportation.

This is a worst case scenario. It probably will not happen. ${ }^{92}$ Our point is simply this: The September 11 attacks and the threat of future terrorism clearly require an intensive investigation. Given the extremity of the threat and identity of the known terrorists, the government is justified in focusing that investigation on Middle Eastern men despite the fact that the public decision to do so has caused understandable pain and anxiety for many Arab Americans. But that should be only the beginning of our inquiry. In the end, what the Department of Justice does to those it seeks to interview, for what reasons and on what basis, are more important than the fact that they may have been initially selected for interviews in part because of their ethnicity or national origin. The same logic applies to other facets of the Government's response to the September 11 attacks that we have not discussed, including the detention in the immediate wake of the terror attacks of several hundred or more foreigners for visa violations. We know little about how these people were selected for detention or why. Suffice it to say, then, that because the consequences for the detainees are very serious, it is highly important that the government act on adequate information and for appropriate reasons.

Is all this to suggest that racial and ethnic profiling is less troubling than we once thought? Not at all. It is certainly true that other racebased practices by the Government can be as bad, or worse, in criminal investigations as elsewhere. Nonetheless we should be deeply suspicious of racial profiling, however mild the government's actions and however

91. See 18 U.S.C. $§ 1001$ (Supp. V 1999).

92. Initial reports on the interview program do not suggest serious abuses. See Jodi Wilgoren, Sweep of Foreign Men Half-Finished as Deadline Passes, N.Y. Times, Dec. 22, 2001 , at B4. 
justified they may appear. Investigative choices that are made on the basis of global assumptions about the criminal propensities of racial or ethnic groups are stigmatizing. They reinforce the negative stereotypes on which they are based because investigators are more likely to detect criminal behavior in groups they target than in the groups they overlook. This is dangerous both because it may be misleading, and because it is humiliating to the targeted group. 1t is a substantial cost of the Justice Department's interview program-whether or not it is ethnic profiling-that many Arab Americans see it as a slap in the face of their entire ethnic group.

Although we have paid close attention to the practical consequences of specific courses of action, we do not think this a simple practical issue. The problem of racially specific investigations cannot reliably be solved by any direct cost-benefit analysis. We should not trust ourselves to make close calls, or even not-so-close calls, in favor of relying on race or ethnicity. It is too common, particularly in a crisis, to exaggerate the threat from a strange or unpopular group, to overstate the effectiveness of an aggressive response, and to underestimate or ignore the costs we inflict on others. Our starting point should be a strong presumption that no racial or ethnic group should be considered more suspicious or dangerous than any other. We have argued against overreliance on labels in evaluating racially specific law enforcement practices. At the same time, however, it is appropriate and important that racial profiling keep its ugly name. 